\title{
Importance of Secondary Plant Metabolites in Plant Protection against Agricultural Insect Pests
}

\section{Sharaby A* \\ Department of Pests\& Plant Protection, National Research Centre, Egypt}

*Corresponding author: Aziza Sharaby, Department of Pests \& Plant Protection, Emeritus Professor of Entomology, National Research Centre, Cairo, Egypt, Email: sharaby_aziza@yahoo.com

\section{Review Article \\ Volume 2 Issue 6}

Received Date: November 04, 2019

Published Date: November 25, 2019

DOI: $10.23880 /$ izab-16000187

\begin{abstract}
Pest management is facing the economic and ecological challenge worldwide due to the human and environmental hazards caused by majority of chemical pesticides. Identification of novel effective insecticidal compounds is essential to combat increasing resistance buildup. Secondary plant metabolites have long been as good alternatives to the chemical insecticides for insect pest managements because it reputedly pose little threat to environment or human health. A number of plant have been considered for use as insect antifeedants, repellents, growth regulators (IGRs) and toxicants. In the context of agricultural pest management, secondary plant metabolism are best suited for use in organic food production in industrialized countries but can play a much greater role in the production and postharvest protection of food in developing countries. Improvement in the understanding of plant allele chemical mechanisms of activity offer new prospects for using these substances in crop protection. Essential oils and plant extracts proved to be safe available alternatives to the synthetic pesticides in plant protection in field and during storage. En-capsulation of essential oils inside nano-particle is a new technology of formulation increasing persistence of the active ingredients, achieve high stability of efficacy, which used as delivery systems and considered as a promising strategy to deliver essential oils in agriculture.
\end{abstract}

Keywords: Plant Secondary Metabolites; Volatile Oils; Plant Extracts; Nano-Formulation

\section{Introduction}

Chemical insecticides designed to kill repell or retard the growth of insect pests that damage or interfere with the growth of crops and other vegetation consumed by humans. All chemical pesticides are poisonous and possess long term danger to the environment and human through their persistence in nature or body tissues [1].
Secondary plant metabolites are naturally occurring chemicals derived or extracted from primary plant metabolites [2]. Primary metabolites directly involved in physiological function in the organisms such as normal growth, development and reproduction for example carbohydrates, proteins, lipids, nucleic acid and hormones. Secondary plant metabolites play an important role in plant defensive against insect herbivores and avoid 


\section{International Journal of Zoology and Animal Biology}

infection by microbial pathogens. Secondary metabolites such Trpenes, Phenolic compound, Coumarin, Lgin, Flavonoids, Tanins sulphur containing, Phytoalexins, Thionin, Lectin, alkaloids, Cyanogenic glucosides and Nonprotein amino acids. Indeed, the scientific literature of past 25 years described hundreds of isolated plant secondary metabolites that showed feeding deterrents or toxic effects to insects in laboratory bioassay, and botanical insecticides have been the subject of several recent volumes [3,4]. There are many factors determining using the secondary plant metabolites for pest control as reported by [5], such as the formulation, the active ingredient, the time of application or exposure, to direct or indirect contact, the quantity used the mixture of substances, the climate and season of the year when it is applied [5]. The first secondary metabolites to be used as pesticides came from easily available products; several recent books have reviewed bio pesticides of plant origin [6]. The present review recorded some essential oils and their constituent of Terpenes with plan extracts that proved effects in protection the agricultural crops in field and during storage. Also the importance of the new technology of essential oils formulation improves both their stability and effectiveness [7].

\section{Plant Essential Oils and Terpenes against Agricultural Insect Pests}

Steam distillation of aromatic plants yield essential oils, long used as fragrance and flavoring in perfume and food industries, more recently as herbal medicines $[8,9]$. The oils are generally composed of complex mixture of mono Terpenes, biogenetically related phenols and sesquiterpenes. A number of the source plants have been traditionally used for protection of stored commodities, but interest in the oils was renewed with emerging demonstration of their fumigant and contact insecticidal activities to a wide range of insect pests [10] Juniper communis L. (Cupressaceae) is a genus of evergreen shrubs or trees, smoke from burnt juniper branches has been used as fumigant to prevent the spread of pathogenic infections [11]. In addition, there are numerous reports on the biological activity of the essential oil of J. communis [12,13]. Sharaby A, et al. [13] reported that J. communis essential oil attracted both sex of the RPW. Hashemi SM, et al. [11] who recorded that J. communis fruit essential oil had insecticidal activity against two stored product beetles, Insecticidal activity varied with essential oil concentration and exposure time. In some cases, oils also may act as poisons, interacting with the fatty acids of the insect and interfering with normal metabolism. Some researchers have demonstrated that essential oils have neurotoxic, cititoxic and mutagenic actions among others in different organisms, and the essential oils act as multiple levels in the insect, so the possibility of generating resistance is little probable [13]. Dhaliwal GS, et al. [5] mentioned that insects' response varied according to oil type, dose and developmental stage. Oils work primarily by covering and suffocating the pest. In some cases, they can disrupt certain membranes of exoskeleton [14]. Khalaf AA, et al. [15] mentioned that protein decreased in $2^{\text {nd }}$ instars larvae of Muscina stabulus treated with oil of Rosmarium officinalis and Cymbopogon citrates. Breuer M, et al. [16] found that Melia azedarach extract inhibited the enzyme activity with $31 \%$ in Leucopphae maderae larvae than in control. Furthermore, while resistance development continues to be an issue for many synthetic pesticides, it is likely that resistance will develop more slowly to essential oil based pesticides owing to the complex mixture of constituents that characterize many of these oils. Recently Yamane $\mathrm{H}$, et al. [17] determined the biological effects of essential oils isolated from Cymbopogon nardus, C.flexuosus and C. martini against two Lepidopterous larvae, the all tested oils showed antifeedant activity and dermal contact lethality against Acharia fusca and Euprosterna elaeasa (Lepidoptera: Emacodidae) at various concentrations. All oils exhibited strong antifeedants and toxicity activity toward the insects. Sharaby A, et al. [18] recorded the toxicity of the tested three different essential oils on the $1^{\text {st }}$ nymphal instar of $\mathrm{H}$. litoralis littoralis is shown in Table 1. Latent toxicity was observed, for this LC50 values were recorded after 14 days from the Steam distillation of aromatic plants yield essential oils, long used as fragrance and flavoring in perfume and food industries, more recently as herbal medicines [8,9]. The oils are generally composed of complex mixture of monoterpenes, biogenetically related phenols and sesquiterpenes. A number of the source plants have been traditionally used for protection of stored commodities, but interest in the oils was renewed with emerging demonstration of their fumigant and contact insecticidal activities to a wide range of insect pests [10] Juniper communis L. (Cupressaceae) is a genus of evergreen shrubs or trees, smoke from burnt juniper branches has been used as fumigant to prevent the spread of pathogenic infections [11]. In addition, there are numerous reports on the biological activity of the essential oil of J. communis [12,13]. Sharaby A, et al. [13] reported that J. communis essential oil attracted both sex of the RPW. Hashemi SM, et al. [11] who recorded that J. communis fruit essential oil had insecticidal activity 
against two stored product beetles, Insecticidal activity varied with essential oil concentration and exposure time. In some cases, oils also may act as poisons, interacting with the fatty acids of the insect and interfering with normal metabolism. Some researchers have demonstrated that essential oils have neurotoxic, cititoxic and mutagenic actions among others in different organisms, and the essential oils act as multiple levels in the insect, so the possibility of generating resistance is little probable [13]. Dhaliwal GS, et al. [5] mentioned that insects' response varied according to oil type, dose and developmental stage. Oils work primarily by covering and suffocating the pest. In some cases, they can disrupt certain membranes of exoskeleton [14]. Khalaf AA, et al. [15] mentioned that protein decreased in $2^{\text {nd }}$ instars larvae of Muscina stabulus treated with oil of Rosmarium officinalis and Cymbopogon citrates. Breuer M, et al. [16] found that Melia azedarach extract inhibited the enzyme activity with $31 \%$ in Leucopphae maderae larvae than in control. Furthermore, while resistance development continues to be an issue for many synthetic pesticides, it is likely that resistance will develop more slowly to essential oil based pesticides owing to the complex mixture of constituents that characterize many of these oils. Recently Yamane $\mathrm{H}$, et al. [17] determined the biological effects of essential oils isolated from Cymbopogon nardus, C. flexuosus and C. martini against two Lepidopterous larvae, the all tested oils showed antifeedant activity and dermal contact lethality against Acharia fusca and Euprosterna elaeasa (Lepidoptera: Emacodidae) at various concentrations. All oils exhibited strong antifeedant and toxicity activity toward the insects. Sharaby A, et al. [18] recorded the toxicity of the tested three different essential oils on the $1^{\text {st }}$ nymphal instar of H. litoralis littoralis is shown in Table 1 . Latent toxicity was observed, for this LC50 values were recorded after 14 days from the Latent toxicity was observed, for this LC50 values were recorded after 14 days from the treatments. According to the LC50 values it could be arranged as follows: Garlic $0.067>$ Eucalyptus $0.075>$ Mint 0.084 $\mathrm{ml} . / 100 \mathrm{ml}$ of diet. A parallel course was obviously seen, a mostly between the mortality and the oil concentration levels. The variable toxicity may be due to the constituents of each oil and disturbance or the hormonal regulations [19], 200 species of plants, which produce chemicals substances able to act against insects, are known. The substances can have poisonous and repellent effects and can work as phagorestrainer ovicide and can affect the insect's hormonal system. Moreover, a great number of essential oils can reduce the reproduction system of several insects and they can also hinder the growth the development and the reproduction of some herbivore insects [20,21]. Koul OS, et al. [22] Found that Cineol and Limonene (terpes) and essential oils of Eucalyptus globulus and E. canaldulensis have shown poisonous effects through the cuticle and in ingestion and fumigation, causing $100 \%$ of mortality of $S$. zeamais in dilution 2:8 (essential oil: acetone). Duke J, et al. [23] proved that E. globulus species has in its composition, 71\% Cineol, pinen, terpinen, anethol, benzaldehyde, estragol, eugenol, limonene, linalool, menthol, methilchavicol, methilicinamate, ocimen, rutin and thimol. The same author recorded that the essential oil of $E$. globulus seem as natural or botanical potential insecticide, once the secondary plant metabolic have been used as pesticides or as models for synthetic pesticides, thus thy can cause poisonous interference in the biochemical and physiologic functions of herbivore insects. Kwonp CS, et al. [24] studded the effect of plant essential oils from 29 plant species for their insecticidal activities against the Japanes termite, Reticukitermes speratus kolabe, using fumigation bioassay, they found good insecticidal effects with essential oils of E. globulus and other E.species and Garlic oil between the other tested oils, Garlic gave $100 \%$ mortality within 2 days of treatment, three major compounds from garlic oil were identified as tri and disulfide. Naganawa R, et al. [25] mentioned that Garlic (Allium sativum) essential oil containing sulfoxide sulfated terpenoids (Allicin, Ajoene), they recorded inhibition of microbial growth by Ajoenen, a sulfur-containing compounds that derived from garlic.

\begin{tabular}{|c|c|c|c|c|c|c|}
\hline \multirow{2}{*}{ Plant Essential Oil } & \multicolumn{2}{|c|}{ LC values mg./100ml. diet } & \multicolumn{2}{c|}{ Fiducial limit } & \multirow{2}{*}{ Slope } \\
\cline { 2 - 7 } & $\mathbf{L C}_{\mathbf{2 5}}$ & $\mathbf{L C}_{\mathbf{5 0}}$ & $\mathbf{L C}_{\mathbf{9 0}}$ & Upper & Lower & \\
\hline Garlic Allium sativum & 0.009 & 0.067 & 2.98 & 0.1038 & 0.031 & 0.7843 \\
\hline Eucalyptus Eucalyptus globulus & 0.008 & 0.075 & 5.23 & 0.1187 & 0.0315 & 0.6951 \\
\hline Mint Mintha pipreta & 0.001 & 0.84 & 215.6 & 0.1723 & 0.0052 & 0.376 \\
\hline
\end{tabular}

Table 1: Susceptibility of the grasshopper $H$. littoralis 1 St instars nymph to the natural plant essential oils mixed with the artificial diet. 
Chaubey MK, et al. [26] found that $\alpha$-pinene and $\beta$ caryophyllene have been evaluated for their repellent, acute toxicity and development inhibitory activities alone and in binary combination against red flour beetle $T$. castanium. In repellency assay, $\alpha$-pinine and $\beta$ caryophyllene repelled T.castanium adults significantly even at $0.025 \%$ concentration. Sharaby A, et al. [27] recorded the insecticidal activity of some terpenes against the cotton leafworm S. littoralis, also Sharaby A, et al. [28] mentioned that terpene Farnesol caused inhibitory effect on growth and development of $S$. littoralos larvae. Terpenes and terpenoids are the most representative molecules constituting $90 \%$ of the essential oils and allow a great variety of structures with diverse functions [29]. Sharaby A, et al. [30] mentioned that the effect of a lot of plants which applied in pests control, are growth regulators because they disturb the growth of pests Figure 1.

\section{Plant Extracts}

Several researches have recorded the entomotoxic properties of the plant extracts from different plant species [31-33]. Sharaby A, et al. [34] who found that Dodonea viscosa extract at 5\% concentration induced $75 \%$ death to Spodoptera littoralis 2nd instar larva fed for one day. The toxicity of $D$. viscosa because of the containment from sterols, viscosol, tannins, and high percentage of flavonoids, alkaloids saponins, coumarins and phenols [35]. Jewers K, et al. [36] recorded R. stricta extract had toxic effect on Culex pipienes, LC50 reached $190 \mathrm{ppm}$. After 10 day post treatment, also alcoholic extract gave larval mortality within two day and LC50 was $251 \mathrm{ppm}$. R. stricta contained high percentage of alkaloids. Dawidar AM, et al. [37] recorded that $C$. schoenanthus contained 11 terpines. Sharaby A, et al. [38] found that $2 \%$ C. citratus oil leading to high toxicity of 3rd instar larvae of Spodoptera. exigua within $2 \mathrm{~h}$. from treatment LC50 reached $0.215 \%$ after 24 hours.

Sharaby A, et al. [34] reported that the extract of some plants as Allium cepa, Curcuma longa, Dodonea viscose and Thuja orientals have adverse effect on the potato tuber moth eggs, Their effects are similar to that caused by JH on the eggs of other insects. Plant extract of Myrtillocactus geometrizans showed insecticidal and insect growth regulatory activity on Spodoptera frugiperda [39]. Melia extracts have antifeedants activity through their effect on $\mathrm{JH}$ that disrupt the growth and development of insects [40]. 30 All plant extracts of Eucalyptus rostrata, Dodonea viscose, Rhyza stricta and Cymbopogon schoenanthus induced different effects as toxicant and growth regulators on tomato fruit worm Helioverpa armigera (Figure 1).
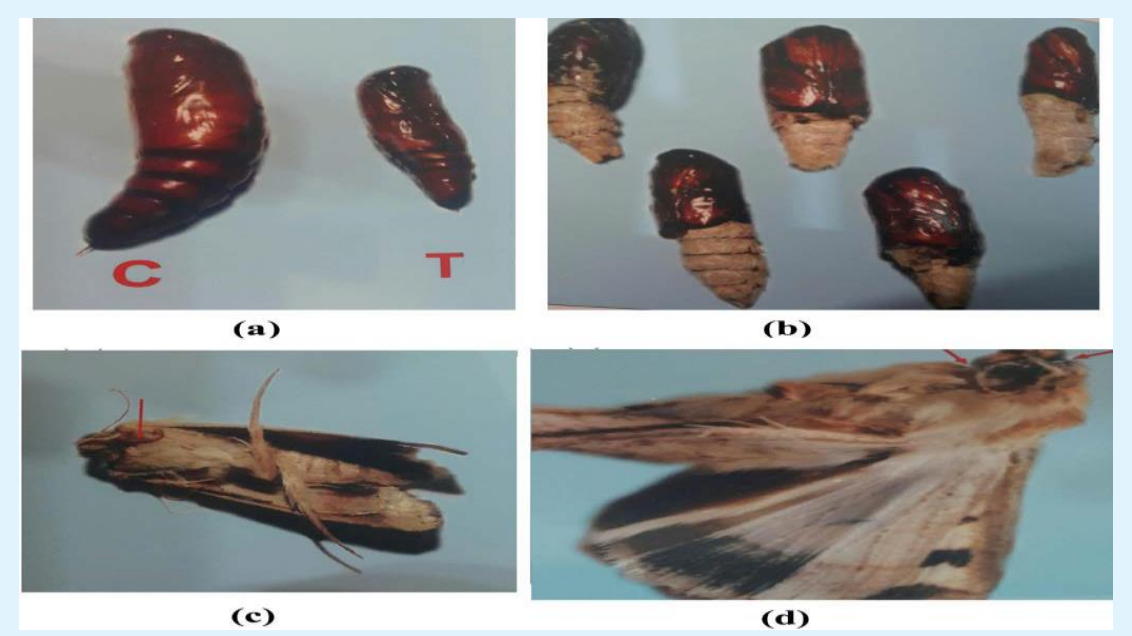

Figure 1: Showing different morphological deformation occurred between pupal and adult stages of H. armigera treated with the different tested. extracts, a: Minute pupa, T, compared with the untreated one C; b: Pupae in intermediate form between papa and adult; c: Deformed moth with twisted legs and minute antennae; d: Deformed moth with twisted wings, and mouth parts with shrinkage abdomen [30]. 


\section{International Journal of Zoology and Animal Biology}
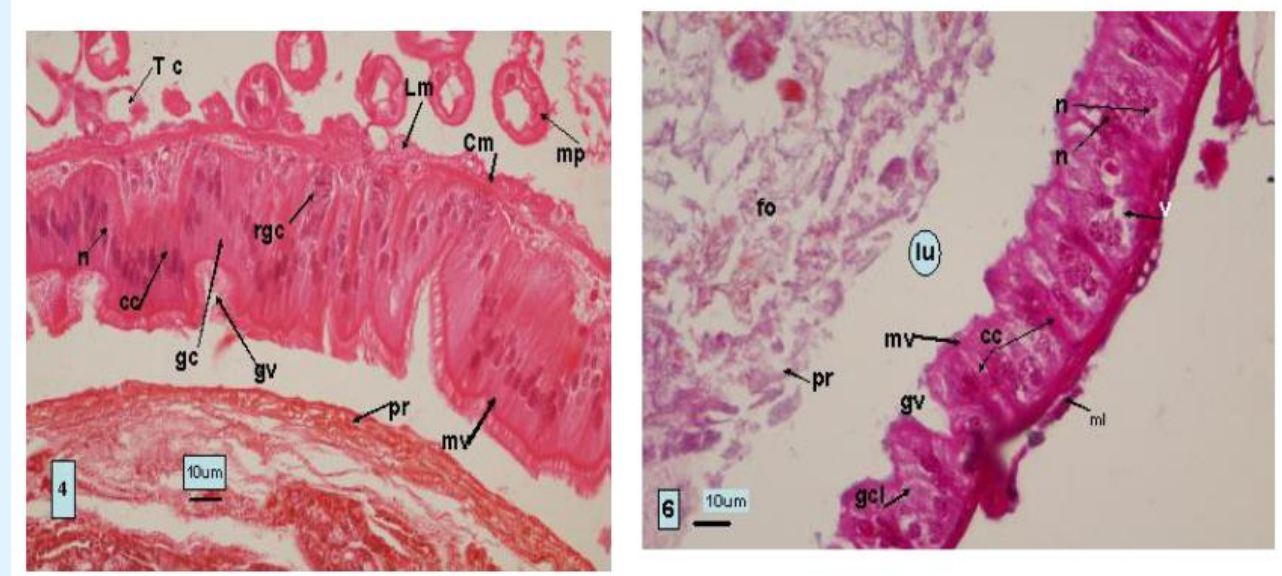

Aprivations: Md: Midgut; mp: Malpighian tubule; ov: Ovary; ts: Testes; int: Intestine; rc: Rectum; an: Anus; ep: Epithelial cells; cc: Columnar cells; gc: Goblet cells; n: Nucleus; gv: Goblet cavity; rgc: Regenerative cells; mv: Microvilli; pr: Peritrophic membrane; cm: Circular muscles; Lm: Longitudinal muscles; Tc: Trachea; V: Vacuoles; gc: Gastric caeca; In: Intiman; Ml: Muscular layer; fc: Fat cells; Fa: Fat droplets; dep: Degenerated epithelial cells; bm: Basement membrane; hg: hindgut; lu: Lumen; fo: Food particles.

Figure 2: 4: TS section in normal mid-gut, 6 TS section in treated mid gut, showing degeneration and rupture of the pretrophic membrane (Pr). Hypertrophy and hyperplasia of the epithelial cells of the treated mid gut.

Many botanical products have been found to act as oviposition and feeding deterrents, ovicidal, larvicidal agent against diverse range of insect pests [41,42]. At the same time, they have very little or no negative effects on beneficial organisms under field conditions [43]. Mainly, Azadirachta indica A. Juss have, substantially, been used in pest management worldwide since years [44]. Also, the seed extract of Milletia ferruginea has been observed to be effective in controlling many insects' pests such as Callasobruchus chinensis, Sitophilus zeamais, Busseola fusca (Fuller), Zebrotes subfaciatus and mosquito larvae [45-49]. Tremendous research is undergoing to evaluate the efficacy of various plant extracts against agricultural insect pests [50]. However, most of these works have been investigated the effectiveness of these plant derived insecticides under laboratory condition. Botanicals areas inexpensive and readily available tools for insect pest management, and eco-friendly. Moreover, the efficacy of aqueous seed extracts of $A$. indica has been also reported against larvae of Spodoptera frugiperda [51]. Combining botanicals with different mode of actions have been reported to be more effective than using them singly which is in correspondence with the previous reports of $[52,53]$. The seed extract of $M$. ferruginea has also been observed to be effective in controlling various insect pests such as; Callasobruchus chinensis [54], Zebrotes subfaciatus [48], adult termites, H. armigera larvae and
Busseola fusca, mosquito larvae [49], ticks and other insect pests [55-61].

\section{Essential Oils Formulation by Nanotechnology for Pest Control}

Although the promising properties of essential oils based pesticides they have negative effects on their application for examples poor solubility, volatility, degradation. En-capsulation of essential oils inside nanoparticle increasing persistence of active ingredients, decrease volatility and their degradation by the weather factors which leading to be active in pest management for long time. Campolo, et al. [7] reported that nano-particles improve the stability and effectiveness of botanical insecticides.

Botanical pesticides based on essential oils and their constituents of Terpenes became to be alternative tool in IPM program Tripathi AK [62] showed toxic, repellent, antifeedants, retardation in development, caused sterilizing effect and affect the reproduction in insect pests [63]. There are some negative properties of the botanical materials such as poor solubility, fast volatility, degradation by weather factors, so en-capsulation inside nano-particles is a good strategy to overcome the previous drawbacks [7] that formulation making it to be 


\section{International Journal of Zoology and Animal Biology}

more stable and effective than if apply as bulk free substances. Beside that they are increasing persistence of the active ingredients. There are some of essential oils were encapsulated in nano-emulsion, to achieves high stability of efficacy, which used as delivery systems and considered as a promising strategy to deliver essential oils in agriculture and particularly in pest management [64].

Genus Achillea is one of the most important genera of family Asteraceae comprising more than 110 species, widespread over the Middle East [65]. The obtained oils Nano-emulsion formulation of Achillea biebersteinii, A.santolina and A.mellifolium considerable toxic and growth inhibitory activities against the red flour beetle, Tribolium castaneum. The oil of $A$. santolina showed the strongest activity introducing malformation in larvae and pupae of T.castaneum. Many of these larvae were failed to shed their soft larval skin and shortly died. As a result, the resulted pupae were smaller in size and the developed adults failed to shed pupal exuviae resulting in the formation of larval-pupil and pupil-adult intermediates as recorded in Figure 1, which were shortly died inside their abnormal integument. The life span and $\mathrm{F}_{1}$ progeny of $T$ castaneum were significantly affected, where the oil of A.sanotolina showed the strongest activity, all of these developmental disruptions led to a great reduction in the number of adults that undergo successful emergence [65].

Neem oil based nanoemulsion has showed good efficiency as compared to synthetic pesticides. The insecticidal activity of the nano-emulsion formulation of neem oil was studied against Sitophilus oryzae and Triboleum castaneum adults. The toxicity effects were significantly more pronounced for the nano-emulsion formulation compared with the crude extract of Neem oil and Neemix under all conditions. The nano-emulsion formulations os neem oil not only caused great mortality of the insects but also increased the speed of azadirachtin action to obtain $100 \%$ mortality. The increase in azadirachtin's speed of action probably is because of the great bioavailability of the active compound of azadirachtin present in the nano-emulsion formulations. The neem oil nano-emulsion formulation for this work increased the effectiveness of azadirachtin with the help of surfactants as compared with a simple, non-formulated crude extract of this compound. A crude extract of neem showed only $30 \%$ mortality at $1 \%$ concentration after 72 hr. of exposure time against T. castaneu.
The citrus peel essential oils (Lemon, Mandarin, and sweet Orange) have the good insecticidal activity against the tomato borer Tuta absolita. While the three formulations of pepper mint oil (bulk, nano-emulsion and nano-encapsulation) showed significant effects on most items of Spodoptera littoralis. Larval duration were prolonged, percentage mortalities were increased as well as larval malformations. Also, pupal duration was prolonged, percentage pupal mortality and pupal malformation [63]. Formulating essential oils into nanoemulsion which is transparent and can be used in food and beverage products, thereby, decreasing the amount of the oil required. Nano-purslane caused complete inhibition of Ephestia cautella and E. kuehniella moth emergence. Geranium essential oil loaded-solid lipid nanoparticle increased insecticidal effect on the development of larval stage of $S$. littoralis and Phthorimaea operculella well as adult longevity and fertility. Oil nano-particles have a much high chemical activity promoting penetration into insect body and enhancing pesticidal activity.

\section{Conclusion}

The plant kingdom offers a rich source of a wide range of structural biodiversity of natural secondary metabolites. One of the most recent trends in fungal and insect pest control is to reduce heavy reliance on synthetic pesticides and to move towards biodegradable substances. Synthetic pesticides of broad spectrum have been widely used as the main tools for controlling weeds, and fungal and insect pest, which are highly toxic to many living organisms as well as to the environment. Hence, new secondary plant metabolites such (plant extracts \&volatile oils) and specific trends to pest control should be developed. In this article, an update of findings in the field were presented, those approaches resulting from the studies on inhibition of growth (including larval growth, pupation, toxicants, and emergence) and of the enzymes involved in key processes of insect life, specially modifying the apolysis during molting, sclerotization, pupation, and emergence. Since these approaches refer to control of insect pests, many of them can be extrapolated and also considered suitable for medicinal chemistry studies, because the mode of action of these inhibitors is similar to that from human and other animals. Therefore, there is an increasing expectation about the research on enzymes inhibition by those compounds of botanical origin that could serve as lead compounds for the development of important substances with agrochemical and pharmacological properties. Thus, by studying the 


\section{International Journal of Zoology and Animal Biology}

plant secondary metabolites that protect plants against the pest attack, we can learn to control this attack in an ecological way and in addition can get pesticide with natural active substances. Their classes are offered good alternative for selective insect pest control that is in harmony with existing integrated pest management program. Nano-encapsulation is currently the most promising technology for protections plants against pests, therefore it will be revolutionize agriculture including pest management in the future. The agriculture would be improved by means of nanotechnology. Several researches on nano-formulations from the secondary plant metabolites open the way for commercialization of nano pesticides which are more targeted delivery of pesticides on the specific can used in IPM of the insect pests.

\section{References}

1. Kumar S (2012) Biopesticides: a need for food and environmental safety. J Biofertil Biopestic 3:4.

2. Mazid S, Kalida JC, Rajkhowa RC (2011) A review on the use of biopesticides in insect pest management. Int J Sci Adv Technol 1: 169-178.

3. Hedin PA, Hollingsworth RM, Masler EP, Miyamoto J, Thompson DG (1997) Photochemical for pest control, ACS symposium series. 658 Washington, DC. American Chemical Society.

4. Regnault-Roger C (1997) The potential of botanical essential oils for insect pest control. Integr pest manage review 2(1): 25-34.

5. Dhaliwal GS, Arora R (2001) Role of photochemical in integrated pest management. In: Koul O, Dhaliwal GS, et al. (Eds.), photochemical biopesticidesic. Harwood Academ Publishers, Amsterdam pp: 97-117.

6. Copping LG, Menn JJ (2002) Biopesticides, a review of their action, application and efficacy. Pest Manag Sci 56(8): 651-676.

7. Campolo 0, Chief A, Ricupero M, Siscaro G, Garssa Lebdi K, et al. ( 2017) Citrus Pell essential oil nanoformulations to control the tomato borer, Tuta absoluta, chemical properties and biological activity. Sci Rep 7(1): 13036.
8. Allen D, Hatfield G (2004) Medicinal plants in folk Tradition, Ethno botany of Britain and Ireland. Timber Press, Cambridge.

9. Bakkali F, Averbeck S, Idaomar M (2008) Biological effects of essential oils a review. Food Chem Toxicol 46(2): 446-475.

10. Sarawar M, Salman M (2015) Toxicity of oils formulation as a new useful tool in crop protection for insect pest's control. Intern J Chem Bio molecular Science 1(4): 297-302.

11. Hashemi SM, Rostaefar A (2014) Insecticidal activity of essential oil from Juniperus communis L. subsp. Hemisphaerica (Presl) Nyman against two stored product beetles. Ecologia Balkanica 6(1): 87- 93.

12. Rizvani S, Rezai MA, Mahmoodi N (2009) Analysis and antimicrobial activity of the plant Juniperus communis. RASAYAN J Chemist 2: 257-260.

13. Sharaby A, Al Dosary M (2014) An Electric Air flow olfactometer and the olfactory response of Rhynchophorous ferrugineus weevil to some volatile compounds. J Agric Ecol Res Int 1(1): 40-50.

14. Brown AE (2005) Mode of action of insecticides and related pest control chemicals for production agriculture, ornamentals and truf. Pesticide Info Leaflet pp: 43: 1-13.

15. Khalaf AA (1998) Biochemical and physiological impact of two volatile plant oils on Muscina stabulans (Diptera: Muscidae). Egypt. Ger Soc Zool Entomol 27: 315-329.

16. Breuer M, Hoste B, DeLoof A, Naqvi SNH (2003) Effect of Melia azedarach extract on the activity of NADPHcytochromec reductase and cholinesterase in insects. Pests Biochem Physiol 76: 99-103.

17. Yamane H, Konno K, Sabelis M, Takabayashi J, Sasss T, et al. (2010) Chemical defense and toxins of plants. Comprehensive Natural Products II 4: 339-384.

18. Sharaby A, Montaser SA, Youssef A, Sobhi AI (2012) Natural Plant Essential Oils for Controlling the Grasshopper (Heteracris littoralis) and their Pathological Effects on the Alimentary Canal, Ecologia Nalcanika 4(1): 39-52. 


\section{International Journal of Zoology and Animal Biology}

19. AL Sharook Z, Balan K, Jiang Y, Rembold H (1991) Insect growth inhibitors from two tropical Meliaceae: effects of crude seed extracts on mosquito larvae. Journal Applied Entomology 111(1-5): 425-530.

20. Hill DS (1990) Pests of stored products and their control. London, Brit Library pp: 274.

21. Partesh S, Santons JP, Waquil JM, Oliveir A (2000) The potential use of substances extracted from Brazilian flora to control stored grain pests. In: Proceedings of the 7th International Working Conference on Stored Product Protection. Beijing, China pp: 820-825.

22. Koul O, Walia S, Dhliwal G (2008) Essential oils as green pesticides: potential and constraints. Bio pesticides International 4(1): 63-84.

23. Duke J (2005) USDA, ARS, National genetic resources program. Phtochemical and Ethnobotanical database (Online). National Germplasm Resources Lab. Beltsville, Maryland.

24. Kwon P, Sang CS (2005) Fumigation activity of plant essential oils and components from Garlic (Allium sativum) and clove bud (Eugeniacaryophyllata) oils against the Japanese termite (Reticulitermes speratus Kolbe). Journal of Agriculture and Food Chemestry 53(11): 4388-4392.

25. Naganawa R, Iwata N, Ishikawa $K$, Fukuda H, Fugino T, Suzuki A (1996) Inhibition of microbial growth by adjoin, a sulfur-containing compound derived from garlic. Applied Environmental Microbiology 62: 42384242.

26. Chaubey MK (2012) Acute, lethal and synergistic effect of some terpenes against Tribolium castaneum Herbst (Coleoptera: Tenebrionidae). Ecologia Bakanica 4 (1): 53-62.

27. Sharaby A (1987) Insecticidal effects of some terpines against the cotton leafworm S. littoralis (Boisd.). Bulletin Entomological Society 16: 31-39.

28. Sharab, A, Magd EL Din M (1990) Inhibitory effect caused by Farnese against the cotton leaf worm $S$. littoralis (Boisd.). Agricon Journal Agriultural Scencesi 17: $1-2$.
29. Cranshaw W S, Baxendale B (2014) Insect control: Horticulture oils. Clorado State University Extension No. 5.569.

30. Sharaby A, AL Dhafer ZM (2019) Some natural plant extracts having biocide activities against the American bollworm Heliecoverpa armigera (Lepidoptera: Noctuidae). Advances in Entomology 7:10-20.

31. Sadek MM (2003) Antifeedant and Toxic Activity of Adhatoda vasica Leaf Extract against Spodoptera littoralis (Lpidoptera: Noctuidae). Journal of Applied Entomology 127(7): 396-404.

32. Sadek M (1997) Antifeedant and Larvicidal Activity Effects of Eichornia crassipes Leaves extract on the Cotton Leafworm Spodoptera litteralis (Boisd.). Journal of Egypt German Society of Zoology 24: 209232.

33. Ulrichs $\mathrm{CH}$, Mews I, Adhikart S, Bhattacharya A, Goswami A (2008) AntifeedantActivity and Toxicity of Leaf Extracts from Portesia coarctata Takeoka and Their Effects on the Physiology of Spodoptera littoralis (F.). Journal of Pest Science 18: 79-84.

34. Sharaby A, Abdel Rahman H, Moawad S (2009) Biological effects of some natural and chemical compounds on the potato tuber moth Phthorimaea operculella Zell. (Lepidoptera: Gelechiidae). Saudi J Biol Sci 16(1): 1-9.

35. Penegelly A (1999) Dodonea viscose. Australian Journal of Medical Herbalism 11: 11-14.

36. Jewers K, Pusey DFG, Sharma SR, Ahmad Y (1980) 13C (Carbon Isotope) NMR Spectral Analysis of Rhazin, Qyebrachamine and Rhazinilam (Isolated from Razya stricta Medicinal Plants. Planta Medica: Journal of Medicinal Plant Research 38: 359-362.

37. Dawidar AM, Emirly ST, Abdel Mogib M (1990) Ssquiterpenes from Cymbopogen schoenanthus L. Pharmazie 45: 296-297.

38. Sharaby A (1988) Anti-Insect Properties of Essential Oil of Lemon Grass, Cymbopogon citrates against the Lesser Cotton Leafworm Spodoptera exigua (Hubn.). In sect Science and Its Application 9: 77-80.

39. Cepedes CL, Avila JG, Marin JC, Dominguez ML, Torres $P$, et al. (2006) Natural compounds as antioxidant and 


\section{International Journal of Zoology and Animal Biology}

molting inhibirots can play a role as a model for search of new botanical pesticides. 3: 1-27.

40. Sieber KP, Rembold H (1983) The effect of azadirachtin on endochrine control of moulting in Locosta migratoria. J Insect Physiol 29(6): 523-527.

41. Silva RS, Tomaz AC, Lopes MC, Martins JC, Xavier VM, et al. (2015) Toxicity of botanical insecticides on Diaphania hyalinata, their selectivity for the predatory ant Paratre china sp., and their potential phytotoxicity on pumpkin. International Journal of Pest Management 62(2): 95-104.

42. Ahmad M, Bilal R, Munir A, Russell DA (2019) Resistance and synergism of novel insecticides in field populations of cotton bollworm, Helicoverpa armigera (Lepidoptera: Noctuidae) in Pakistan. Journal of Economic Entomology 112(2): 859-871.

43. Begg GS, Cook SM, Dye R, Ferrante M, Franck P, et al. (2017) A functional overview of conservation biological control. Crop Protection 97: 145-158.

44. Hussain D, Muhammad S, Ghulam G, Muneer A (2015) Insecticide Resistance in field population of Helicoverpa armigera (Hubner) (Lepidoptera: Noctuidae). Journal of Entomological Science 50(2): 119-128.

45. Mulatu B (2007) Contact bioassay of an endemic plant to Ethiopia on three aphid species. Ethiopian Journal of Biological Science 6(1): 51-62.

46. Jembere B (2002) Evaluation of the toxicity potential Millettia ferruginea Hochest Baker against Sitophilus zeamais moths. International Journal of Pest Management 42(1): 29-32.

47. Tilahun B, Azerefegn F, Reddy KMS (2009) Bioassay and residual toxicity of Baker tree Millettia ferruginea (Hochst) seed crude water extract against maize stalk borer Busseola fusca (fuller) (Lepidoptera: Noctuidae), $1^{\text {st }}$ (Edn.), Office of Research and Publication, Dilla University, Dilla pp: 12.

48. Habeeb SM (2010) Ethno veterinary knowledge of crude plant extracts and its methods of application traditional and modern for tick control. West African Applied Science Journal 11(9): 1047-1050.

49. Asegid S, Abede D, Mudi K, Melaku D, Taye G (2007) Screening of some Ethiopian medicinal plants for mosquito larvicidal effects and phytochemical constituents. Pharmacology 3: 3231-3243.

50. Zanuncio JC, Mourão SA, Martínez LC, Wilcken CF, Ramalho FS, et al. (2016) Toxic effects of the neem oil (Azadirachta indica) formulation on the stink bug predator, Podisus nigrispinus (Heteroptera: Pentatomidae). Scientific Report 6: 30261.

51. Birhanu S, Tefera T, Wakgari M, Ayalew G, Mendesil E (2019) The Efficacy ofselected synthetic insecticides and botanicals against Fall armyworm, Spodoptera frugiperda, in Maize. Insects 10: 2-45.

52. Sharma H, Gowda C, Stevenson P, Ridsdill Smith T, Clement S, et al. (2007) Host plant resistance and insect pest management in chickpea. In: chickpea breeding and management, CABI, Wallingford, Oxon, UK pp: 520-537.

53. Younas A, Waqas W, Zaeema K, Muhammad S, Sean MP (2016) The efficacy of Beauveria bassiana, jasmonic acid and chlorantraniliprole on larval populations of Helicoverpa armigera in chickpea crop ecosystems. Pest Management Science 73(2): 418424.

54. Mulatu B, Gabremedhin T (2000) Oviposition deterrent and toxic effects of various botanicals on the Adzuki Bean Beetle, Callosobruchus chinensis L. Insect Science \& Its Application 1: 33-38.

55. Jembere B, Getahun D, Negash M, Seyoum M (2006) Toxicity of Birbira (Milletiaferruginea) seed crude extracts to some insect pests as compared to other botanical and synthetic insecticides. pp: 88-96.

56. Lulie N, Raja N (2012) Evaluation of certain botanical preparations against Africanbollworm, Helicoverpa armigera Hubner (Lepidoptera: noctuidae) and nontarget organisms in chickpea, Cicer arietinum L. Journal of Biofertilizer \& Biopesticides 3: 130.

57. Fite T, Tefera T, Negeri M, Damte T, Sori W (2018) Management of Helicoverpaarmigera (Lepidoptera: Noctuidae) by nutritional indices and botanical extracts of Millettia ferruginea and Azadirachta indica. Advance in Entomology 6: 235-255.

58. Tilahun B, Azerefegne F (2013) Efficacy of the aqueous crude seed extract of Millettia ferruginea (Fabaceae) on the maize stemborer Busseola fusca 
(Lepidoptera: Noctuidae) in the field. International Journal of Tropical Insect Science 33(4): 256-263.

59. Choudhury MK, Shiferaw Y, Hussen A (2015) Toxicity of Millettia ferrugineadarasana (family: Fabaceae) against the larvae and adult ticks of Amblyomma variegatum Fabricius a three-host tick in cattle. Journal of Parasitic Diseases 39(2): 298-302.

60. Damte T, Chichaybelu M (2002) The efficacy of some botanicals in controlling Adzuki bean beetle, Callosobruchus chinensis in stored chickpea. Tropical Science 42: 192-195.

61. Eyob T, Azerefegne A, Tameru, Temesgen A, Blomme G (2010) Studies on the efficacy of some selected botanicals against insect root mealybug (Cataenococcus ensete) Williams and Matile-Fererro (Homptera: seudococcidae). Tree \& Forestry Science \& Biotechnology 4(2): 91-94.
62. Tripathi AK, Upadhyay S, Bhuiyan M, Bhattacharya PB ( 2009) Areview on prospects of essential oils as biopesticides in insect- pest management. J Pharmacogn Phytother 1(5): 52-63.

63. Isman MB (2000) Plant essential oils for pest and disease management. Crop Protection 19(8-10): 604608.

64. Liu WT (2006) Nanoparticles and their biological and environmental applications. J Biosci Bioeng 102(1): 17.

65. Candan F, Unlu M, Tepe B, Daferera D, Polissiou M, et al. (2003) Antioxidant and antimicrobial activity of the essential oil and methanol extracts of Achillea millefolium Afan (Asteraceae). J Ethnopharmacol 87: 215-220. 